\title{
Decoloniality, Language and Literacy
}




\section{STUDIES IN KNOWLEDGE PRODUCTION AND PARTICIPATION}

Series Editors: Mary Jane Curry, University of Rochester, USA and Theresa Lillis, The Open University, UK

Questions about the relationships among language and other semiotic resources (such as image, film/video, sound) and knowledge production, participation and distribution are increasingly coming to the fore in the context of debates about globalisation, multilingualism and new technologies. Much of the existing work published on knowledge production has focused on formal academic/scientific knowledge; this knowledge is beginning to be produced and communicated via a much wider range of genres, modes and media including, for example, blogs, wikis and Twitter feeds, which have created new ways of producing and communicating knowledge, as well as opening up new ways of participating. Fast-moving shifts in these domains prompt the need for this series which aims to explore facets of knowledge production including: what is counted as knowledge, how it is recognised and rewarded, and who has access to producing, distributing and using knowledge(s). One of the key aims of the series is to include work by scholars located outside the 'centre', and to include work written in innovative styles and formats.

All books in this series are externally peer-reviewed.

Full details of all the books in this series and of all our other publications can be found on http://www.multilingual-matters.com, or by writing to Multilingual Matters, St Nicholas House, 31-34 High Street, Bristol BS1 2AW, UK.

\section{Editorial Board}

Jannis Androutsopoulos, University of Hamburg, Germany

Karen Bennett, Universidade Nova, Portugal

Jan Blommaert, Tilburg University, the Netherlands

Rebecca Black, University of California, USA

Sally Burgess, Universidad de La Laguna, Spain

Paula Carlino, University of Buenos Aires, Argentina

Christine Casanave, Temple University, USA

Christiane Donohue, Dartmouth College, USA

Guillaume Gentil, Carleton University, Canada

Bruce Horner, University of Louisville, USA

Dawang Huang, University of Ningbo, China

Luisa Martín Rojo, Universidad Autonoma, Spain

Carolyn McKinney, University of Cape Town, South Africa

Françoise Salager-Meyer, Universidad de Los Andes, Venezuela

Elana Shohamy, Tel Aviv University, Israel

Sue Starfield, University of New South Wales, Australia

Christine Tardy, Arizona State University, USA

Lucia Thesen, University of Cape Town, South Africa 
STUDIES IN KNOWLEDGE PRODUCTION AND PARTICIPATION: 3

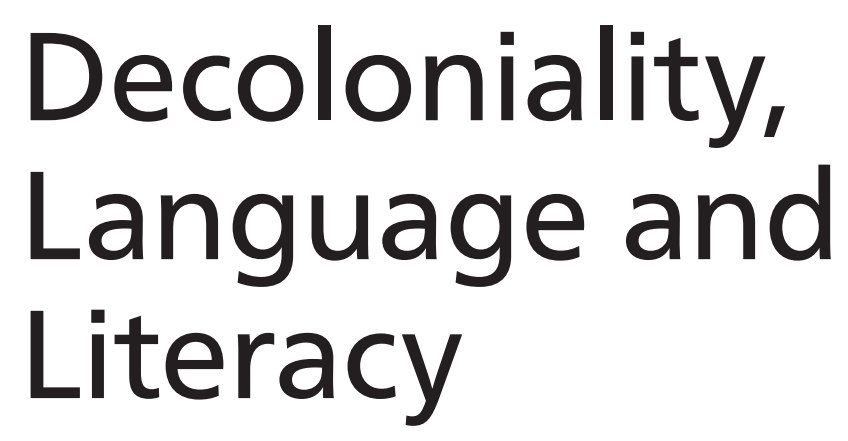

Conversations with Teacher Educators

\section{Edited by \\ Carolyn McKinney and \\ Pam Christie}


DOI https://doi.org/10.21832/MCKINN9240

Library of Congress Cataloging in Publication Data

A catalog record for this book is available from the Library of Congress.

Names: McKinney, Carolyn, editor. | Christie, Pam, editor.

Title: Decoloniality, Language and Literacy: Conversations with Teacher

Educators/Edited by Carolyn McKinney and Pam Christie.

Description: Bristol, UK; Blue Ridge Summit, PA: Multilingual Matters, 2022.

Series: Studies in Knowledge Production and Participation: 3 |

Includes bibliographical references and index. | Summary: "Through a

range of unconventional genres, representations of data, and dialogic, reflective narratives alongside more traditional academic genres, this book engages with contexts of decoloniality and border thinking in the Global South. It captures the learning that takes place beyond the borders of disciplines and formal classroom spaces"- Provided by publisher. Identifiers: LCCN 2021037268 (print) | LCCN 2021037269 (ebook) | ISBN 9781788929233 (paperback) | ISBN 9781788929240 (hardback) | ISBN 9781788929257 (pdf) | ISBN 9781788929264 (epub)

Subjects: LCSH: Education-Developing countries. | Non-formal educationDeveloping countries. | Language and education-Developing countries. |

Literacy-Developing countries. | Teachers-Training of-Developing countries. Classification: LCC LC2605 .D36 2022 (print) |

LCC LC2605 (ebook) | DDC 370.9724-dc23

LC record available at https://lccn.loc.gov/2021037268

LC ebook record available at https://lccn.loc.gov/2021037269

British Library Cataloguing in Publication Data

A catalogue entry for this book is available from the British Library.

ISBN-13: 978-1-78892-924-0 (hbk)

ISBN-13: 978-1-78892-923-3 (pbk)

\section{Multilingual Matters}

UK: St Nicholas House, 31-34 High Street, Bristol BS1 2AW, UK. USA: Ingram, Jackson, TN, USA.

Copyright (C) 2022 Carolyn McKinney, Pam Christie and the authors of individual chapters.

All rights reserved. No part of this work may be reproduced in any form or by any means without permission in writing from the publisher.

The policy of Multilingual Matters/Channel View Publications is to use papers that are natural, renewable and recyclable products, made from wood grown in sustainable forests. In the manufacturing process of our books, and to further support our policy, preference is given to printers that have FSC and PEFC Chain of Custody certification. The FSC and/or PEFC logos will appear on those books where full certification has been granted to the printer concerned.

Typeset by Nova Techset Private Limited, Bengaluru and Chennai, India. Printed and bound in the UK by the CPI Books Group Ltd. 